\title{
4. 超高齢者の降圧目標
}

\author{
横手幸太郎
}

Key words : 超高齢者, 百寿者, 高血圧, 薬物療法, ADL

（日老医誌 $2007 ； 44 ： 445-447$ )

\section{はじめに}

高齢人口の増加に伴い, 65 歳以上の高齢者のうち 74 歳までの人々を前期高齢者, 75 歳以上を後期高齢者と 呼び分けることが多くなってきた、“超高齢者”の定義は 必ずしも統一されていないが，一般には 85 歳以上を指 すようである．2004 年に策定されたわが国の高血圧治 療ガイドラインでは, 高齢者の高血圧について“80歳 前半までは積極的な治療を行うべきである”とし, 前期・ 後期高齢者に分けて降圧目標を示している ${ }^{1)}$. しかし, 85 歳以上の患者については，十分なエビデンスがないとし て明確な管理目標は提示されていない（表 1).

このように，降圧目標を含めた超高齢者の血圧管理に ついては, 80 歳前半までの高血圧患者に関するエビデ ンスの延長線上で個々の医師の判断に任されているのが 現状である。日本人男性の平均寿命は 78.6 歳, 女性は 85.6 歳（2004 年）だが， 85 歳まで生きながらえた男性 ではさらに 6.1 歳, 女性の場合は 8.1 歳の平均余命が期 待できることからも, 超高齢者の血圧管理について考え る機会は重要と思われる ${ }^{2)}$.

そこで超高齢者の降圧目標について, 幾つかの研究成 績を元に考察を行った.

\section{百寿者の ADL と血圧値}

超高齢者は，すでに国民の平均寿命を達成していると いう点に扔いて“長生きのエリート”と考えることがで きよう。そのような人たちが降圧療法を通じてさらに目 指すべき目標は何か？一つのゴールともいうべき，究極 の超高齢者である 100 歳以上の人々（以下，百寿者）の

Blood pressure management in the very elderly Koutaro Yokote: 千葉大学大学院医学研究院細胞治療 学 (糖尿病 - 代謝 · 内分泌内科)
実態について考えてみたい.わが国における百寿者の数 は，1965 年には 153 人であったが，2005 年には 25,554 人に達している。長寿者が増えることは喜ばしい限りで あるが，百寿者のうち自立している者が 2 割に過ぎず， 4 割は寝たきり，という事実を目の当たりにすると思い は複雑である。

日本の百寿者で特に罹患率が高い疾患は, 第 1 位が白 内障 $(42.9 \%), 2$ 位が骨折 $(42.5 \%)$ ，そして第 3 位が 高血圧 $(29.2 \%)$ であり, 特に脳卒中は百寿者の ADL （日常生活活動度）と負の相関を示した（高山美智代, 広瀬信義ら, personal communication)。一方, 百寿者 における高血圧の合併はバーセル指数で評価した ADL （日常生活活動度）と正の相関関係にあり，また正常血 圧に比べ $140 / 90 \mathrm{mmHg}$ 以上あるいは $160 / 90 \mathrm{mmHg}$ 以 上と血圧が高めの人々ほどより高いバーセル指数を示し た. 横断的研究であるため, 双方の因果関係を結論する ことはできないものの, 百寿者にむやみな降圧を強いる ことに警鐘を鳴らす結果と思われる。一方，日本人にお ける脳卒中罹患者数は 50 歳代から増え始め 100 歳代に 至るまで年齢とともに増加を示したのに対し, 高血圧の 罹病者は 30 歳から 70 歳代までは年齢を重ねるごとに増 え続けたものの，百寿者では大きく減少していた。この 対比は, 特に高血圧による“ダメージ”を受けやすい人

表 1 高血圧治療ガイドライン 2004 による高齢者の降 圧目標

\begin{tabular}{|c|c|}
\hline 区分 & 降圧目標（mmHg） \\
\hline $\begin{array}{l}\text { 前期高齢者 } \\
(65 \sim 74 \text { 歳 })\end{array}$ & 140/90未満 \\
\hline $\begin{array}{l}\text { 後期高齢者 } \\
\text { (75 } 84 \text { 歳) }\end{array}$ & $\begin{array}{l}140 / 90 \text { 未満 } \\
\text { 中等症・重症高血圧(収縮期血压 } 160 \text { 以上)の } \\
\text { 場合, } 150 / 90 \text { 未満を暫定目標とする }\end{array}$ \\
\hline $\begin{array}{l}\text { 超高歯者 } \\
(85 \text { 歳〜) }\end{array}$ & (明確な数值目標の設定は無い) \\
\hline
\end{tabular}




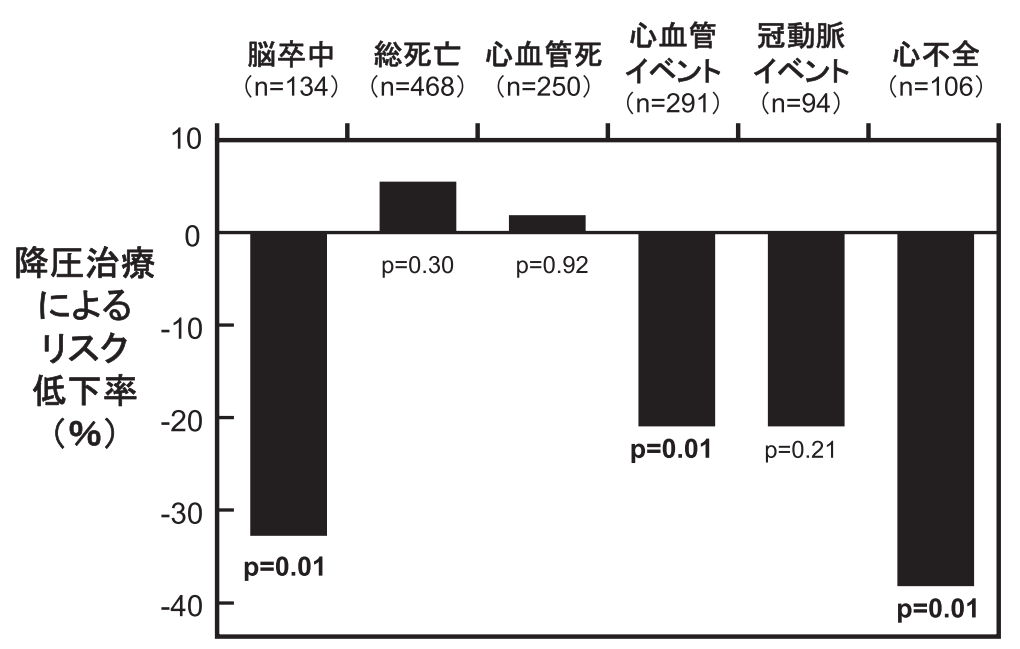

図 180 歳以上の高齢者を対象とした降圧療法の有用性に関するメ夕解析 80 歳以上の高血圧患者に対する積極的な降圧は脳卒中，心血管イベント，心不全の発生を有意に抑制 したが，総死亡や心血管死には有意な影響を及ぼさなかった。（文献 9 より引用）

たちの多くが 100 歳に到達する前に死亡してしまうこと を反映している可能性があり，少なくとも 100 歳以前で は適切な降圧管理が有用であることをうかがわせる.

\section{超高齢者高血圧の臨床試験}

被験者の平均年齢が 70 歳以上の, プラセボを対照と した降圧剤を用いた大規模臨床試験には， $\mathrm{EWPHE}^{3)}$, $\mathrm{SHEP}^{4)}, \mathrm{STOP}^{5)}, \mathrm{MRCII}^{(6)}$, Syst-Eur ${ }^{7)}$ な゙があるが, いずれもコントロールに比して心血管イベントの発症を 20４0\% 抑制することを示している．また，1つのイべ ントを防ぐために必要な降圧治療患者数（NNT：Number needed to treat）について年齢別に考えた場合，総 死亡，心血管死，心血管イベントやその内訳など主たる 評価項目のすべてに扔いて“70歳以上群”は“60〜69 歳群”に比べて低い值を示した，すなわち 70 歳以上の 方が治療の効率が良い，というメ夕解析結果も示されて いる ${ }^{8}$.

80 歳以上の高齢者に対する降圧療法の有用性を評価 したメ夕解析の結果によると, 積極的な降圧は脳卒中, 心血管イベント，心不全の発生を有意に抑制したが，総 死亡や心血管死には有意な影響を及ぼさなった（図 $1)^{9}$. 死亡を減らせなかったのだから 80 歳以上の降圧は 無意味である，とも評価されうる結果だが，果たしてそ うだろうか?これまでに世界中で実施されてきた大規模 臨床試験の多くは青壮年あるいはせいぜい初老期の患者 を対象としており，最重要視されるアウトカムは確かに “死亡の有無”であった。 ところが前述したように, “寿 命”という観点において超高齢者は，いわば成功者であ
る，そのような集団では，死亡もさることながら“生活 の質”に直結する要因への評価がより重視されるべきで はないか?つまり，ADLの低下をもたらす脳卒中，心 血管イベント，心不全の発生を抑えられるのであれば, それだけでも高齢者の降圧には意味があると評価できる.

80 歳以上の高血圧患者を対象とした唯一のプラセボ 対照試験として, HYVET (The Hypertension in the Very Elderly Trial）がある．年齢 79.5 96.1 歳，血圧 值 160〜219/90〜109mmHg の 1,283 名を対象とした 13 カ月間のパイロット試験では, 降圧目標を $150 / 80 \mathrm{mmHg}$ 未満として ACE 阻害剤または利尿剤を使うことによ り，脳卒中の発生を有意に抑制したが，心血管死と総死 亡には影響がなかった（図 2) ${ }^{10}$. 現在，2,100 名を対象 とした多施設二重盲検ランダム化比較試験として本試験 が実施されており，超高齢者の降圧目標について一つの 指針を与えてくれるものと期待される.

なお， 60 歳以上を対象としたSHEP 研究の解析結果 によれば，降圧介入後の収縮期血圧值が $150 \mathrm{mmHg}$ 未 満の群は脳梗塞発症リスクが有意に減少したものの, 140 $\mathrm{mmHg}$ 未満へ低下した群ではプラセボ群との間に有意 差がなかった11).また他の研究では治療後の搪張期血圧 が $60 \mathrm{mmHg}$ 未満に下がるとかえって心血管イベントの 発生が増えることが示されている（図 3) ${ }^{122}$.

\section{おわりに：日常の診療を踏まえて}

このように考えてくると，まず，超高齢であっても良 いADL が保たれている場合，高血圧に対する降圧治療 は十分に推奨できる. では，主題である降圧目標はどうか？ 

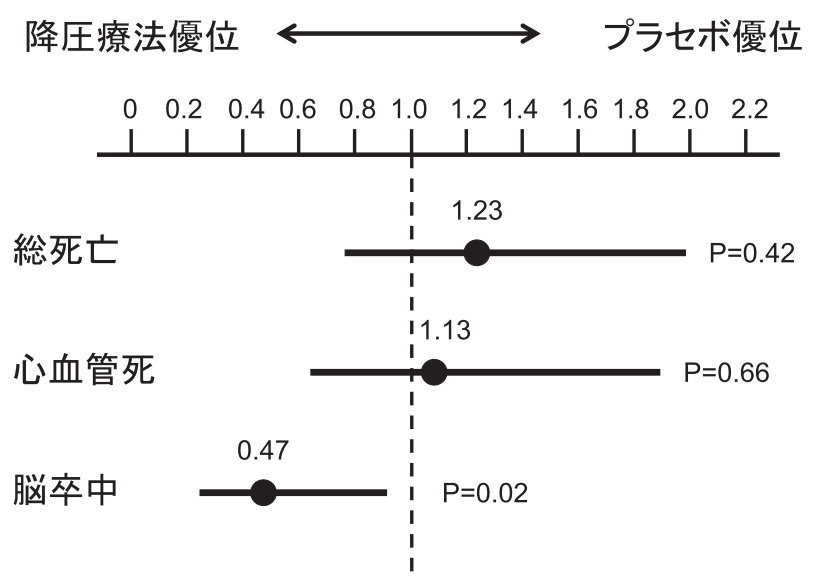

図2 HYVET パイロット研究の主要成績 80 歳以上の高血圧患者を対象とした前向き試験の結果, 降圧剂治療により脳卒中の発生が有意に抑制されたが, 心血管死と総死亡には影響がなかった，数值は相対八 ザード比を示す。（文献 10 より引用）

個人的な経験として, 独歩で外来に通う 90 歳代前半 の女性患者 2 症例に多剂併用による降圧治療を実施し， 元気に 100 歳を迎えていただけるという機会があった. これらの患者が家庭で記録した血圧を今振り返ってみる と, 110〜 160/60～90mmHg と, その到達血圧值はまち まちであった，但し，結果的には収縮期血圧で 150〜160 $\mathrm{mmHg}$ 未満, 拡張期血圧 $60 \mathrm{mmHg}$ 以上という本稿でた どり着いたエビデンスの範囲に収まっていたようである.

したがって，これらの数值をおおまかな管理目標とし て捉え, その他に転倒・骨折の誘引となる過度の降圧や 起立性低血圧を生じないよう十分に配慮しながら個人の 特性に応じて治療を行う。そして, 結果として最善の生 命予後と生活予後（ADL \& QOL）を得ることを超高齢 者の降圧目標として提案したい.

\section{参考文献}

1）日本高血圧学会高血圧治療ガイドライン作成委員会 : 高 齢者高血圧. 高血圧治療ガイドライン 2004 , ライフサ イエンス出版, p54-63.

2）厚生労働省：平成 16 年簡易生命表. http://www.mhlw. go.jp/toukei/saikin/hw/life/life04/

3) Amery A, Birkenhaeger W, Brixko P, Bulpitt CJ, Clement D, Deruyttere M, et al: Mortality and morbidity results frome the European Working Party on High Blood Pressure in the Elderly Trial. Lancet 1985; i: 13491354.

4) SHEP Cooperative Research Group: Prevention of stroke by antihypertensive drug treatment in older persons with isolated hypertension: final results of the Systolic Hypertension in the Elderly Program (SHEP).

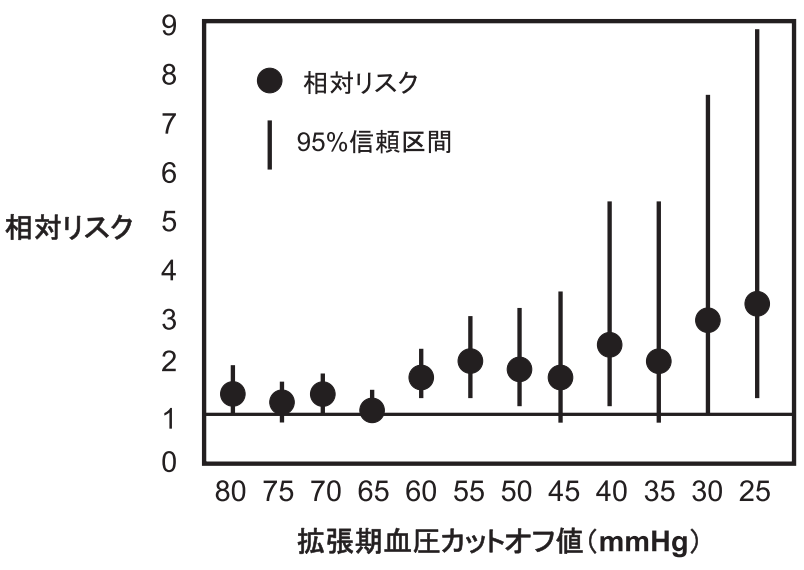

図 3 拡張期血圧のカットオフ值別にみた心血管イベン ト発症の相対リスク

60 歳以上の高血圧患者に対する降圧治療で, 拡張期血 圧が $60 \mathrm{mmHg}$ 未満に低下するとかえって心血管イベ ントの発生が増えることが示唆されている.（文献 12 より引用)

JAMA 1991; 265: 3255-3264.

5) Dahloef B, Hansson L, Lindholm LH, Schersten B, Ekbom T, Wester P-O: Morbidity and mortality in the Swedish Trial in Old Patients with Hypertension (STOPHypertension). Lancet 1991; 338: 1281-1285.

6) MRC Working Party: Medical Research Council trial of treatment of hypertension in older adults: principal results. BMJ 1992; 304: 405-412.

7) Staessen JA, Fagard R, Thijs L, Celis H, Arabidze GG, Birkenhager WH, et al: Randomised double-blind comparison of placebo and active treatment for older patients with isolated hypertension. Lancet 1997; 350: 757764.

8) Staessen JA, Gasowski J, Wang JG, Thijs L, Den Hond E, Boissel JP, et al.: Risks of untreated and treated isolated systolic hypertension in the elderly: meta-analysis of outcome trials. Lancet 2000; 355: 865-872.

9) Gueyffier F, Bulpitt C, Boissel JP, Schron E, Ekbom T, Fagard R, et al.: Antihypertensive drugs in very old people: a subgroup meta-analysis of randomised controlled trials. INDANA Group. Lancet 1999; 353: 793-796.

10) Bulpitt CJ, Beckett NS, Cooke J, Dumitrascu DL, Gil-Extremera B, Nachev C, et al.: Hypertension in the Very Elderly Trial Working Group: Results of the pilot study for the Hypertension in the Very Elderly Trial. J Hypertens 2003; 21: 2409-2417.

11) Perry HM Jr, Davis BR, Price TR, Applegate WB, Fields WS, Guralnik JM, et al: Effect of treating isolated systolic hypertension on the risk of developing various types and subtypes of stroke: the Systolic Hypertension in the Elderly Program (SHEP). JAMA 2000; 284: 465471.

12) Somes GW, Pahor M, Shorr RI, Cushman WC, Applegate WB: The role of diastolic blood pressure when treating isolated systolic hypertension. Arch Intern Med 1999; 159: 2004-2009. 